\title{
SAY 125 TIMES 'YES': BOSNIA AND HERZEGOVINA IN THE UN SECURITY COUNCIL
}

\author{
Peter Plenta \\ International University of Sarajevo, Bosnia and Herzegovina \\ Ajla Smaka \\ Independent Researcher, Bosnia and Herzegovina
}

\begin{abstract}
Membership in the Security Council was one of the greatest achievements for Bosnia and Herzegovina after gaining the independence. Serving as a non-permanent member for the period of 2010 and 2011, it faced challenges mostly related to its capacity building and decision-making process in foreign policy. During this two-year period, the Council adopted 125 resolutions and two resolutions suffered veto, both regarding Middle East. Bosnia and Herzegovina had an affirmative stand in regards to all resolutions discussed. However, it faced difficulties forming a stand towards questions of Kosovo and Palestine. The attitude and voting behavior of Bosnia and Herzegovina was not influenced by other states nor the relationship between them, but by internal issues. Our article provides analysis, evaluation, and interpretation of particular topics, such as the independence of Kosovo, Iran's nuclear program, situation in Libya, Palestine and situation in Bosnia and Herzegovina itself discussed in the Security Council in 2010 and 2011, with the explanation of the attitudes of Bosnia and Herzegovina.
\end{abstract}

Keywords: The Security Council; Resolutions; Voting; Bosnia and Herzegovina

\section{Introduction}

When Bosnia and Herzegovina was elected as a non-permanent member of the Security Council in the period of 2010 and 2011, many questions and controversies were raised. For some it was a surprise, for some a disappointment and others were proud. The ability of Bosnia and Herzegovina to cope with all challenges and tasks which this membership brings, was questionable as for 'locals', so for 'foreigners'. Moreover, media coverage in Bosnia and Herzegovina was very poor and this topic is not covered in the academic field as well.

Bosnia and Herzegovina went through an armed conflict that took place between 6 April 1992 and 14 December 1995. Although the country passed through many transitions in the history, the last war had the biggest impact. After the war, Bosnia and Herzegovina faced challenges related to internal and external affairs, such as implementation of the system set by the Dayton Peace Agreement and building an internationally recognizable image of a sovereign state. Strive for the development and international recognition led Bosnia and Herzegovina to the path of the European Union* and NATO. Great opportunity and progress came with the membership in the Security Council. Although Bosnia and Herzegovina faced difficulties concerning capacities and lack of knowledge or experience, especially concerning issues related to Africa and Asia, it showed that it is capable of

\footnotetext{
* The most important step on Bosnia and Herzegovina's path to EU membership was signing the Stabilization and Association Agreement (SAA), in Luxembourg on 16 June 2008. Although Bosnia and Herzegovina is struggling on this path for a very long time, just modest progress has been made.
} 
working with states which possess all that Bosnia and Herzegovina lacked. However, the country had an affirmative stand regarding all adopted resolutions.

Considering that most, if not all, of the mandate was a learning experience for Bosnia and Herzegovina, presiding** the Security Council was even more challenging than the rest of the mandate. Most challenges, especially at the beginning of the mandate were caused by lack of knowledge and experience concerning certain topics discussed. As Bosnia and Herzegovina was never dealing with issues regarding Côte d'Ivoire, for instance, it was difficult to take stands and discuss the matter. Another difficulty presented lack of people on the ground. As some other states, especially permanent members had their representatives all around the world and therefore they had the first hand information about situation and events in a particular country, Bosnia and Herzegovina did not. According to Ambassador Barbalić, representatives from Turkey and Croatia, who served their term starting in 2009, contributed largely in overcoming difficulties and getting familiar with the processes that occur in the Security Council (Barbalic 2015).

The main goal of this article is to analyze the work of the Security Council and resolutions discussed in the period of 2010 and 2011 with the focus on voting behavior of Bosnia and Herzegovina. In this two-year period 125 resolutions were adopted and two resolutions suffered veto. As this membership carries huge importance, these two years present crossroads in terms of the efficiency and capability of participation and engagement in international peace and security and its evaluation is certainly significant. This developing country which was discussed in this body roughly twenty years ago came to a position to engage actively in maintaining international peace and security and contribute to countries in need. For all these reasons, this topic is valuable for as for internal so for external politics and community and it can provide insight of Bosnia and Herzegovina's political and diplomatic development as well as effectiveness of the UN Security Council. For the purpose of this paper, we have conducted an interview with Ambassador Ivan Barbalić, who was the head of the Bosnia and Herzegovina's mission in New York. Additionally, meeting records and press releases were used as well.

This article provides analysis of resolutions concerning Kosovo, Islamic Republic of Iran, Libya, Palestine, and Bosnia and Herzegovina. These resolutions were challenging for all members of the Council. As one of the member states, Bosnia and Herzegovina found itself in a difficult position discussing these issues and in several cases it was questionable which stand the state will take due to its internal and external affairs, all of which will be discussed further on in the article. Despite all of that, the attitude of Bosnia and Herzegovina in the Security Council was not influenced by other member states, but by its own internal issues, attitudes, and goals.

\section{Bosnia and Herzegovina's Candidacy}

It goes without saying that the Security Council carries great responsibilities concerning the whole world, and its importance and influence remained significant since it has been founded. However, according to David Bosco, the UN Security Council has been more active in the past twenty years than during any other phase of its existence (Bosco 2014: 545). The Council has met more frequently, authorized more peacekeeping and observation missions, and enacted more sanctions regimes and arms embargos than in its first four decades.

\footnotetext{
** Member states are taking turns according to English alphabetical order in presiding the Security Council. Bosnia and Herzegovina was presiding in January 2011.
} 
Bosnia and Herzegovina have been striving for development and political recognition on an international scene since it gained independence. The mandate in UN Security Council Bosnia and Herzegovina got for the first time presented a great step in its international politics and, as several analysts assumed, a great chance to bring Bosnia and Herzegovina closer to its membership in European Union and NATO. The real opportunity for Bosnia and Herzegovina's term in the Security Council came in 2008 when Poland indicated its withdrawal as a candidate and confirmed it in 2009 providing a chance for membership in the Security Council. As Bosnia and Herzegovina was the only candidate from the Eastern European states, its candidacy was approved and it served as a non-permanent member in the Security Council from January 1, 2010 to December 31, 2011 with 183 votes. In 2009, the Ministry of Foreign Affairs has performed an intensive campaign aimed for Bosnia and Herzegovina to get the required majority in the UN General Assembly and serve the term in the Security Council. Minister of Foreign Affairs has conducted dozens of bilateral meetings and visits, perhaps even more than was necessary in considering the fact that Bosnia and Herzegovina was the only candidate (Vanjskopolitička inicijativa 2011:2). Members of the presidency of Bosnia and Herzegovina were actively engaged in this as well so they visited to the United Nations headquarters more often than usually.

After the election of Bosnia and Herzegovina in the Security Council, many people including local political analysts as well as local politicians and diplomats assumed or predicted that this mandate will contribute Bosnia and Herzegovina in several aspects. Strengthening bilateral relations, improvement on the path to the membership to European Union and NATO, and higher foreign investments were most commonly mentioned. Ambassador at-large, Miloš Prica, mentioned it in the interview conducted for the local newspapers 'Nezavisne novine' when he said that successful work in the Security Council opens many international doors and if the membership is at the level it should be, it will be a big plus in all processes in international relations of Bosnia and Herzegovina (Prica 2009).

Another view, presented by the Federal News Agency (FENA), was that activities in the Security Council were guided towards the realization of the basic goals set when the decision for the application for the membership in the Security Council was made such as the affirmation of Bosnia and Herzegovina at the international level and contribution to solving the world's problems from the perspective of Bosnia and Herzegovina as a multiethnic and multicultural state; contribution to the activities of the Security Council aimed at conflict prevention and peaceful resolution of the crisis existing in the world, and contribution to the activities in the field of post-war construction of society and monitoring of post-conflict situations, particularly in the areas of establishing and ensuring the rule of law, institution building, human rights and sustainable return of refugees and displaced persons (FENA 2012). Expectations regarding the membership were very high and sometimes even far from reality. Ambassador Barbalić said that we could not expect the membership in the Security Council to bring certain changes to Bosnia and Herzegovina. "Being in Security Council shows that you are practically allowing yourself to accept huge responsibility to participate in this important process that exists in the multilateral world, you are not there to achieve something, but to make sure to help countries that need help, to achieve it" (Barbalić 2015).

While high level politicians and diplomats from Bosnia and Herzegovina had positive and optimistic views regarding the membership, negative or doubtful stands 
were often presented in the media. The mission did not enjoy the support from media and therefore was often graded as incapable of coping with the tasks that the membership brings. At one point, there were claims that Bosnia and Herzegovina was assigned with the easiest task, namely working groups, ${ }^{* * *}$ in the Security Council due to the lack of experience. In the interview conducted by journalist Erol Avdović, ambassador Barbalić strongly disagreed stating that "working groups" represent one of the highly important diplomatic tool significant for the Council's work (Barbalic 2012). In addition to that, media also emphasized that disagreement between the members of the presidency conflicted with the success of the mission. However, it is important to mention that the members of the presidency reached an agreement in about 97 percent of the cases. Hence, this presents the success for the country with such ethnical diversity and complex government structure.

During its two-year mandate, Bosnia and Herzegovina found itself in an unenviable position. As it was present in the Council as one of its members, at the same time the situation in the country was discussed. This included reports form the High Representative and resolution regarding the continuation of presence of the EUFOR Althea mission in the country. Further on, the disagreement among presidency members regarding the situation in the state and its development occurred. All of this did not contribute to the image of Bosnia and Herzegovina as a member state. However, this situation was not specific only for Bosnia and Herzegovina and therefore was not the only case a member state faced during its mandate.

Prior to the beginning of the mandate it was necessary to establish a system and build a team which will carry on the mission and cooperate with the government in Sarajevo. The only official document that defines B\&H foreign policy are the Basic Directions of B\&H Foreign Policy created in 2003 (Vanjskopolitička inicijativa 2011: 3). The document does not provide clear guidance and as this was the first time for Bosnia and Herzegovina to be a part of a body such as the Security Council, an efficient team and communication network needed to be established. Critics and doubts about Bosnia and Herzegovina's capability to justify its membership in the Security Council and participate in high level diplomacy were often and common which created additional pressure to members of the mission. For instance, David Bosco criticized the decision to elect Bosnia to the presidency over the Security Council citing that Bosnia's membership on the council is largely "symbolic" and that "the General Assembly needs to stop carping about Council reform and start consistently electing states that can contribute to peace and security, not those barely able to govern themselves (Bosniak 2011). Moreover, decisions regarding Bosnia and Herzegovina's stand in the Security Council are made by presidency members. All three members (Bosniak, Croat, and Serb) need to agree upon certain issue unanimously in order for Bosnia and Herzegovina to take stand in the Security Council.

As some were predicting failure to cope with all challenges that this membership brings, some believed that this was the time to shine. Optimistic views were mainly coming from domestic politicians and diplomats and doubts were coming manly from media. Membership in the Security Council certainly is a challenge and both views can be justified in a way. Can a country facing numerous internal issues advocate wellbeing of other states? The attitude and decisions made by Bosnia and Herzegovina during 2010

\footnotetext{
**** The UNSC has dozens of working groups responsible for various global issues handled by the UN, which requires a large administrative apparatus in the countries' missions to the UN, as well as in the UN Secretariat, which provides technical and expert support (In Vanjskopolitička Inicijativa, 2011, pp. 2).
} 
and 2011 answered this question and justified positive and/or negative views which will be discussed further on in this article.

Resolutions of the Security Council often represent the final step for a discussed issue discussed. The work of the Security Council in the period of 2010 and 2011 was successful if we take in account the level of accord between members and number of resolutions adopted. Majority of the resolutions which required voting were adopted unanimously. During the interview, ambassador Barbalic noted that in 90 percent of decision there was not any kind of obstacle and pretty much it was clear what direction the majority Security Council were to go and basically the presidency would without any problem agree upon (Barbalić 2015). Despite that, in the term of 2010 and 2011, the Council had faced difficulties in reaching the consensus several times. Decisions concerning Iran, Libya, and Palestine brought up different stands from member states. In addition to that, discussing the situation in Kosovo as well as situation in Bosnia and Herzegovina was particularly difficult for representatives of the county. The origin of the difficulty lies in the internal issues and ethnical diversity played a significant role. During Bosnia and Herzegovina's two-year mandate in the Security Council, 125 resolutions were adopted. Bosnia and Herzegovina had an affirmative stand towards all ladopted resolutions without.

\section{Resolutions 2010}

Majority of meetings and resolutions adopted in 2010 were concerning Africa and Asia. Another great concern of the Security Council was protection of civilians in armed conflict and women vulnerable to sexual violence. Nuclear proliferation remained the concern as well in respect of Iran and the Democratic People's Republic of Korea. Members held 182 public meetings, adopted 59 resolutions, and issued 30 presidential statements in 2010 (The United Nations 2011b). Additionally the Security Council was holding many meetings behind the closed doors. Out of 59 adopted resolutions, only six of them required vote $^{* * * *}$ and none of the permanent members' casted veto. The highest number of open meetings - a total of 14 - was devoted to the question of Palestine as the prospects of peace talks in the Middle East waxed and waned (The United Nations 2011b). After devastating earthquake, the Security Council reinforced the United Nations Stabilization Mission in Haiti twice. One of the major decisions made in 2010 was the lifting of restrictions on Iraq which was imposed nearly 20 years ago.

Not so long ago, in 1990s, Bosnia and Herzegovina was topic of discussion and concern of the Security Council. In relatively short period of time such as fifteen years, it was discussing about mayor issues threatening international peace and security and taking stands regarding them. Despite the tempestuous past marked with interethnic conflict, decisions and stands formed were not guided by the country's experience. Rather, the armed conflict that Bosnia and Herzegovina went through had mostly symbolic impact.

\footnotetext{
${ }^{* * * * *}$ Resolutions about which consensus was not reached were following: Security Council resolution on establishment of the International Residual Mechanism for Criminal Tribunals with two branches and the adoption of the Statute of the Mechanism, where Russia abstained from voting; Security Council resolution on termination of all residual activities under the Oil-for-Food Programme, where France abstained from voting; Security Council resolution on extension of the mandate of the UN Peacekeeping Force in Cyprus (UNFICYP), where Turkey voted against; Security Council resolution on extension of the mandate of the UN Panel of Experts Established pursuant to Security Council Resolution 1591 (2005), where China abstained from voting; Security Council resolution on extension of the mandate of the UN Peacekeeping Force in Cyprus (UNFICYP), where Turkey voted against; Security Council resolution on measures against the Islamic Republic of Iran in connection with its enrichment-related and reprocessing activities, including research and development, where Brazil and Turkey voted against and Lebanon abstained from voting.
} 
Nonetheless, as ambassador Barbalić said, "it is important symbolism, I would say, brick in the wall of our statehood being a member of the Security Council it is an important element to CV of a country" (Barbalic 2015). For the previously discussed reasons, internal issues and lack of knowledge and experience regarding certain issues discussed, many challenges occurred. Several resolutions adopted by the Security Council were particularly challenging for Bosnia and Herzegovina including difficulties regarding decision making process due to internal situation.

Situation in Kosovo was one of the issues discussed in the Security Council in 2010. Although Kosovo declared independence from Serbia in 2008, it still continue to be the concern of Serbian government and violence between Serbians and Albanians living in that territory keep on. International Court of Justice proclaimed the independence of Kosovo legal, however Serbia is still opposed its existence as an independent state. The center of events was northern region of Mitrovica. Serbian government claimed that Albanians living in Kosovo are maltreating Serbs living in that area. Term often used by Serbian representatives regarding that issue included 'ethnic cleansing'. These claims were rejected by the Kosovo's government.

The Security Council met five times discussing this issue and each time it was calling on dialog. All meetings included briefing by Lambert Zannier, Head of the United Nations Interim Administration Mission in Kosovo (UNMIK) about the development of situation in Kosovo. While Kosovo's representatives claimed that the situation is improving and that they are ready to work closely with Serbian government in order to resolve issues, Serbian government was opposing those claims and still questioning the independence. Vlora Çitaku, minister of Foreign Affairs at the time in Kosovo, said to the Council that there was significant progress in building democratic institutions in Kosovo and that there is a platform for starting a technical dialogue with Serbia on missing persons, cooperation against crime and corruption, mutual recognition of documents and phone networks and other issues of mutual interest (The United Nations 2010a).

Serbs living in Bosnia and Herzegovina keep close ties with Serbia. Therefore, it was most likely that Serb member of the presidency would support Serbia in issues such as Kosovo. For this reason, discussing Kosovo case in the Security Council was one of the biggest challenges Bosnia and Herzegovina faced during its mandate. There were no resolutions concerning Kosovo which required voting, however representatives still needed to take a stand and comment presented situation. These stands included support for negotiations and acknowledging the importance of UNMIK. Considering the procedure of the decision making process, Bosnia and Herzegovina could not and did not take the position on the question of Kosovo's independence.

Aside from protection of civilians, non-proliferation was one of the major concerns in 2010 as well. The Security Council had already imposed sanctions several times on Islamic Republic of Iran because of its nuclear program. The threat was acknowledged because of Iran's ongoing program to enrich uranium which can be potentially used for nuclear weapons. The United States government was lobbying imposition of new sanctions. By 9 June, deeply concerned about Iran's lack of compliance with its previous resolutions on ensuring the peaceful nature of its nuclear program, the Council adopted resolution 1929 (2010) by 12 in favor to 2 against (Brazil, Turkey), with 1 abstention (Lebanon) to impose additional sanctions, expanding the arms embargo and tightening restrictions on financial and shipping enterprises related to proliferation-sensitive activities (The United Nations 2010f). 
Bosnia and Herzegovina and Islamic Republic of Iran have good and stable bilateral relations. These two countries have been cooperating continuously and working on strengthening their relations especially in the field of trade and economy. When Iranian non-proliferation was discussed in the Security Council and before the voting, the attitude of Bosnia and Herzegovina regarding that topic was highly doubted in media. Regional and international journalists raised question whether Sarajevo will declare its support for Teheran or not. According to unofficial findings of media, presidency of Bosnia and Herzegovina received from Iranian officials a list of reasons why they should not support imposing sanctions against Iran trying to persuade them to vote against the resolution (Moj Portal 2010).

Before the voting took place, there were predictions that Turkey, Brazil, and Lebanon will vote against the resolution, and similar stands were expected from Uganda and Nigeria considering their relations with Iran. Additionally, Russia and China were likely to abstain from voting which would leave decision upon Bosnia and Herzegovina whose stand was not clear at the time. The United States put a lot of effort into persuading resolution's passing. Bosnia and Herzegovina has good relations both with Washington and Tehran. Despite all of that, it took positive stand along with other member states except Turkey, Brazil, and Lebanon which enabled adoption of the resolution (Radio Sarajevo 2010).

Despite all doubts and predictions, Bosnia and Herzegovina still supported imposing sanctions against Iran. The very next day after the voting took place in the Security Council, Iranian Ambassador in Sarajevo Gholamreza Yousefi met with the member of presidency at the time Nebojša Radmanović to discuss possible improvement of bilateral cooperation between these two countries especially in the field of trade and economy. Bosnian 'Yes' did not cause negative feelings from Tehran.

The situation in Bosnia and Herzegovina was on the agenda of the Security Council three times during 2010. This included two briefings by High Representative, Valentin Inzko, and resolution regarding the authorization of the European Union Stabilization Force (EUFOR) for another year. Each year, the High Representative is briefing the Security Council twice about situation in Bosnia and Herzegovina and development the country made for certain period of time.

During the first briefing in 2010, he spoke about current situation and development as well as the implementation of the Dayton Peace Agreement. Internal issues and politics was still very complicated and it was not clear whether the government strives for more centralized or decentralized state. He also said that the country could not take advantage of certain economic assistance, and had made no progress on the five goals and two conditions - the so-called " $5+2$ Agenda" — set by the Steering Board for the transition from the Office of High Representative to a reinforced European Union-led presence (The United Nations 2010b). Chairman of the Presidency of Bosnia and Herzegovina at the time Haris Silajdžić, who spoke at the meeting as well, emphasized the effect of so called entity vote which exists in the political system. It allows Republika Srpska to block any decision proposed by Federation and vice versa.

The second briefing was held on November 11. This time, together with the High Representative Valentin Inzko, chairman of the Presidency of Bosnia and Herzegovina at the time Nebojša Radmanović spoke to the Council as well. During the briefing, the High Representative concluded that nationalist agendas were still prevailing over cooperation and compromise, making the political situation difficult and that there had been no 
progress in the past year on the key reforms required for Bosnia and Herzegovina's integration into Euro-Atlantic structures (The United Nations 2010g). On the other hand, Radmanović said that the progress has been made and that the situation in the country changed since the last briefing. He also claimed that all key elements of the Dayton Peace Agreement had been implemented, that situation is more stable, and that the country has made progress regarding Euro-Atlantic integrations.

Meeting held on November 11 was about prolonging European Union Stabilization Force in Bosnia and Herzegovina. EUFOR ALTHEA mission ${ }^{* * * * *}$ in Bosnia and Herzegovina started in December 2004 after NATO decided to end SFOR mission. The main purpose of the ALTHEA mission is maintenance of peace set by the Dayton Peace Agreement. All member states realized that this mission and its perseverance was still significant for Bosnia and Herzegovina. Therefore resolution was adopted unanimously authorizing the mission for another year - until 18 November 2011.

Briefings by the High Representative did not provide any basis for optimistic views and the fact that the presence of EUFOR ALTHEA mission is necessary shows that the country still needs assistance with maintenance of previously made the Dayton Peace Agreement as well as establishment of future agreement (EU integration). Although Bosnia and Herzegovina was not the only state in this situation, it was not easy for representatives to be present in the Security Council while the situation of the country was discussed without optimistic views. Decision makers had clear stand regarding this resolution, along with other member states. However, the importance or the difficulty of this resolution lies in the unpleasant situation that discussion about these topics brings for a member state concerning its own issues.

Year 2010 was challenging for the Security Council. The importance of protection of civilians, non-proliferation, and conflicts that occurred throughout the world were the major issues member states were concerned about. The biggest obstacles that Bosnia and Herzegovina faced at the beginning of the mandate were related to building capacities and forming a team which will carry out the mission in the Security Council. Lack of knowledge regarding particular issues certain countries are facing made this mandate more difficult. However, internal issues still prevailed in the decision making process.

The external affairs did not affect the stand as we can see from the resolution about non-proliferation in Iran. Although Bosnia and Herzegovina has very good and stable relations with Iran, that did not prevent voting in favor for the resolution and therefore agreeing on imposing sanctions. On the other hand, internal issues contributed largely when the Council discussed Kosovo case. Also, discussing the situation in Bosnia and Herzegovina during its mandate was not easy for members of the mission especially because presented situation did not signalize progress. 2010 was concluded with 59 'yeses' coming from Bosnia and Herzegovina, along with Austria, Gabon, Japan, Mexico, Nigeria, Uganda, the United Kingdom, and the United States, which might indicate the effectiveness of decision making process in the Council and agreement among member states.

\footnotetext{
The operation is a part of EU approach to Bosnia and Herzegovina and the significant contribution of the EU's political engagement and its assistance programs (the current police and monitoring mission) in order to help further progress towards European integration in the light of the stabilization and accession process (EUFOR B\&H).
} 


\section{Resolutions in 2011}

One of the main concerns of the Security Council in 2011 was, once again, protection of civilians. Massive protests that occurred worldwide in 2011 largely contributed to the importance of this topic. Majority of resolutions and meetings were held regarding problems in Africa. The Security Council held 213 public meetings in 2011, slightly more than in 2010. Number of resolutions adopted is slightly larger as well, counting 66 resolutions. Member states strove for consensus once again. Only five resolutions required a vote. ${ }^{* * * * * *}$ Unlike in 2010, two resolutions suffered vetoes in 2011 both concerning Middle East situation. The birth of South Sudan as an independent country and events in Côte d'Ivoire drew the attention of the Security Council as well. The Council established peacekeeping mission in South Sudan and Sudan. After the declaration of independence, the membership of South Sudan in the United Nations was considered as well. Post elections conflict in Côte d'Ivoire resulted in sprawling violence. The threat of harm for civilians increased and thousands of citizens were felling the country. Hundreds of military and police personnel were sent to ensure the wellbeing of citizens.

So called Arab Spring that started in Tunisia in December 2010, continued spreading across Arab countries in 2011. Peace and security was threatened in many countries including Morocco, Kuwait, Libya, Egypt, Lebanon, etc., and other conflicts were still ongoing - Bahrain, Sudan, and Syria. Massive protests and attempts to overthrow government became the concern of the Security Council. Protests that began in Libya on February 2011 proceeded to an armed conflict that lasted eight months. These events turned into an armed conflict between Libyan security forces and citizens seeking to overthrow Qadhafi's rule. The Council's formal engagement started on February 25, 2011 and in 19 formal meetings spanning the conflict's duration, the Council's most significant actions included imposing sanctions on the Qadhafi regime, approving the no-fly zone and authorizing the use of 'all necessary measures' to protect civilians (The United Nations 2012). Six resolutions were adopted in relation to situation in Libya in 2011.

Considering the escalation of events the Security Council was forced to react quickly. First resolution was adopted on February 26, which demanded the end of violence and referred the situation to the International Criminal Court. Sanctions included freezing assets belonging to the Quadhafi family, travel ban, and arms embargo was imposed. Humanitarian agencies were called to Libya and committee for monitoring the situation was established. This resolution was adopted unanimously.

The Council adopted second resolution in regards to situation in Libya by 10 votes in favor, none against, and five abstentions - Brazil, China, Germany, India, Russian Federation on 17 March. This resolution demanded immediate ceasefire. Member states agreed that strong action against Quadhafi regime was necessary and no-fly zone was enforced. However, the representatives of China and the Russian Federation called for a peaceful settlement of the conflict, with the latter noting that the text left many questions unanswered, including how and by whom the measures would be enforced and what the

\footnotetext{
Resolutions concerning which consensus was not reached were: Security Council resolution on measures against Eritrea and expansion of the mandate of the Monitoring Group re-established by resolution 2002, where China and Russia abstained from voting; Middle East situation - where China and Russia casted veto, and Brazil, India, Lebanon, South Africa abstained from voting; Security Council resolution on extension of the mandate of the Panel of Experts Established pursuant to Resolution 1929 (2009) concerning the Islamic Republic of Iran until 9 June 2012, where Lebanon abstained from voting; Security Council resolution on establishment of a ban on flights in the Libyan Arab Jamahiriya airspace, where Brazil, China, Germany, India, and Russia abstained from voting, and resolution concerning Middle East situation, including the Palestinian question where the United States casted veto.
} 
limits of engagement would be (The United Nations 2012). In addition to these two, four more resolutions were adopted all demanding ceasefire and imposing sanctions to the authorities.

Rapid development of events in Libya was the concern of all Security Council members including Bosnia and Herzegovina. Although the Security Council did not succeed in ensuring safety for civilians and preventing or stopping the conflict, member states cooperated continuously in order to find a solution. Bosnia and Herzegovina did not have a subjective stand regarding these issues, but made the decisions in consultation with other member states in order to prevent escalation of events.

Unlike for situation in Libya, Bosnia and Herzegovina had more subjective attitude towards issues regarding Middle East, especially Palestinian question. As Bosnia and Herzegovina is composed of three constituent people, representatives of each strive towards sustaining their beliefs and interests therefore looking for like-minded ones beyond the border as well. As Serbs try to maintain their connection with Serbia and Russia, Croats with Croatia, Bosniaks try to establish and sustain the connection with Muslims in other parts of the world too. This shows how internal issues can be expanded beyond borders reflecting to the complex Israeli-Palestinian situation. In addition to this, the relational ties that exist between Israel and smaller B\&H entity, Republika Srpska, prevailed in the decision making process. The two often provide support for each other and Republika Srpska was even called as Israel's best friend in Europe by Michael Freund (Freund 2014). The question of Palestine is dating since 1947, when the General Assembly decided to divide the territory into Arab and Jewish part. Ever since then, this issue raised many controversies and resulted into many conflicts. As it was part of many discussions in the Security Council for decades, this topic was brought up again in 2011.

Two resolutions related to Middle East suffered veto in 2011. First proposed resolution in February was concerning Israeli settlements on Palestinian territory. The United States has casted veto which prevented adoption of this resolution. The US ambassador, Susan Rice, said that this resolution might harden positions of both sides and encourage them to stay out of negotiations and that Washington view was that the Israeli settlements lacked legitimacy (The Guardian 2011).

Bosnia and Herzegovina found itself in an unenviable position when Palestine decided to seek full UN membership through the Security Council. Although diplomatic relations between these two countries exist, the Presidency had a hard time reaching consensus necessary to take a positive or negative stand. Because of the inability of all three members of the presidency to reach the decision unanimously, if it had come to voting, abstention would be the only choice. According to Bosco, seven members were likely to support - Brazil, China, India, Lebanon, Nigeria, Russia, and South Africa; two leaning in that direction - Bosnia and Herzegovina and Portugal; three who are probably on the fence - France, Gabon, and the United Kingdom; two likely to oppose - Colombia and Germany; and one certain to oppose - the United States. Close ties with Israel contributed to these possible stands as well as the effect it might leave on the other countries as well. Whether this resolution had necessary nine votes or not, it was doomed to fail because the Unite States would still cast a veto preventing the adoption. Bosnian Serb leaders strongly oppose the Palestinian initiative due to ties with Israel and, especially, belief that this action could lead to a similar move by Kosovo (Bosco 2011). Regarding this resolution Milorad Dodik, president of the Republika Srpska, said for the Jerusalem Post, "We did not hesitate to adopt a pro-Israel position. I am proud of this stance that we took "(Freund 2014). 
During the interview, Ambassador Barbalić mentioned that this was not a good time for Palestine to seek full membership in the United Nations through the Security Council considering the member states it was composed of at the time. However, it is very questionably if convenient time will ever come taking in account that the United States is one of the permanent members and its ties with Israel. Later on, Palestinian government decides to withdraw the application for the membership.

Second resolution regarding Middle East was discussed in the Council in October. The draft resolution was in regards to the situation in Syria and imposing sanctions against the regime. It was drafted by France in cooperation with Britain, Germany and Portugal. This resolution had support of nine members including Bosnia and Herzegovina; however, this was not enough for the adoption because Russia and China, joined forces in casting veto. Member states which abstained from voting are: Brazil, India, Lebanon, and South Africa.

Situation in Bosnia and Herzegovina itself was on the agenda in the Security Council during second year of its mandate as well. If we take in account just this particular subject, 2011 pretty much mirrored 2010. As in previous year, two briefings by the High Representative were held and resolution regarding EUFOR ALTHEA mission was discussed. Political situation continued to develop negatively and no progress has been made regarding European Integration process and membership to NATO. The development of country was threatened in every aspect.

First briefing by the High Representative Valentin Inzko was held on 9 May when he expressed his concern regarding the maintenance of the order set by the Dayton Peace Agreement. The threat was faced when the authorities in the Republika Srpska decided to take actions which violate the Dayton Peace Agreement. By deciding to hold a referendum that would put into question the High Representative's authorities and laws enacted by him, as well as other State-level institutions, including the Bosnia and Herzegovina Court, the Republika Srpska's National Assembly had opted for a path that represented a 'serious breach' of the country's constitutional framework and was contrary to the 1995 peace deal that ended nearly four years of inter-ethnic fighting (The United Nations 2011a). This did not contribute to building positive image of the country; on the contrary, it was characterized as the worst political crisis that Bosnia and Herzegovina faced since the end of the war.

Second briefing by the High Representative was held on 15 November. During this briefing, the High Representative Inzko congratulating Bosnia and Herzegovina on its tenure as a member of the Security Council, said that had given the Government the opportunity to make new friends and gain the respect of many countries; it should be counted as a significant foreign policy success (The United Nations 2011d). He also added that despite the global crisis, economic progress had been made. However, political instability continued and he argued that his presence as the High Representative and EUROR mission were still essential. This briefing was followed by negative comments by Russian representative who said that the briefing can be hardy called objective and that in order to justify his position, the High Representative deliberately emphasized the negative view on the situation in the country.

As in 2010, third and the last time the situation in Bosnia and Herzegovina was discussed in the Security Council in 2011, referred to the EUFOR ALTHEA mission. Once again this resolution was adopted unanimously by all member states considering that the presence of the mission was still crucial to ensure preserving peace set by the Dayton 
Peace Agreement. As a result, the mission was prolonged yet for another year. Bosnia and Herzegovina was still not capable of ensuring peace and security for its citizens and succeeding in political and economic development on its own.

In a year characterized by many uprisings all over the world and some of them escalating into armed conflicts such as events related to the Arab Spring, the importance of protection of civilians grew. The development of events forced the Security Council to react quickly and impose serious sanctions such are those imposed on Quadhafi family. The success of the Council in assuring protection of civilians and ending conflicts is questionable. However, the cooperation between member states and strive to achieve set goals (implementation of resolutions) was on a high level.

\section{Conclusion}

During 2010 and 2011 situation in Bosnia and Herzegovina was characterized by political instability, budget deficit, and stagnation in the european integration process and membership to NATO. On the other hand, if we look at the bright side, it achieved a great success by becoming a non-permanent member of the Security Council and carrying its mandate successfully. Major obstacles at the beginning of the mandate were related to capacity building. While other member states had teams composed of numerous experts reaching even up to fifty members of the mission, Bosnia and Herzegovina had only fifteen people at disposal in New York. As Ambassador Ivan Barbalić highlighted, the team had a hard time coping with all obligations set by the Council due to shortage of personnel. Insufficient experience in body such as the Security Council as well as lack of knowledge in regards to certain issues discussed, presented an obstacle as well.

In the period of 2010 and 2011, wide range of topics were discussed in the Security Council, 125 resolutions were adopted and two resolutions suffered veto. Consensus was reached in great majority of them. Bosnia and Herzegovina voted in favor for every resolution discussed. Despite all of that, it faced inevitable challenges along with other member states. This paper provides an insight of the following topics discussed in the Security Council with the focus on voting behavior of member states, particularly Bosnia and Herzegovina: Kosovo, Islamic Republic of Iran, Libya, Palestine, and Bosnia and Herzegovina.

Situation in Bosnia and Herzegovina was discussed three times in each year of its tenure. This included two annually briefings by the High Representative and resolution regarding the EUFOR ALTHEA mission. Even fifteen years after the end of the war, international guardians of the Dayton Peace Agreement were still crucial for the country. Political and economic instability in the country which did not lean towards progress, might justify negative views regarding country's membership in the Security Council which occurred prior to the beginning of a tenure. On the other hand, despite all of that, country's representatives worked side by side with other member states and managed to fulfill the expectations.

The Security Council held 182 public meetings, adopted 59 resolutions, and issued 30 presidential statements in 2010 . None of the permanent members casted veto and only six resolutions required a vote. Major concerns of the Council was protection of civilians in an armed conflict and women vulnerable to sexual violence. In regards to the Islamic Republic of Iran and Democratic People's Republic of Korea, nuclear proliferation remained a concern as well. The Security Council had already imposed sanctions on Iran regarding nuclear weapons program. The United States was lobbying the Council to pass 
the resolution imposing new sanctions. It was very debatable which stand Bosnia and Herzegovina will take regarding this resolution. Despite the help it got from Iran during the war and good bilateral relations, Bosnia and Herzegovina still voted in favor of this resolution. Iranian representatives announced that they understand the stand that Sarajevo took. Members of the Presidency agreed unanimously upon this issue. However, when the issue of Kosovo was discussed, Serbian member of the Presidency has more subjective stand which was expected considering ties Bosnian Serbs hold with Serbia. This issue did not come to vote, still representatives spoke during the meetings when this issue was discussed. They called to negotiations and acknowledged the importance of UNMIK, but did not take position regarding Kosovo's independence.

The Security Council held 213 public meetings in 2011, adopted 66 resolutions, and issued 22 presidential statements in 2011. Only five resolutions required a vote; however two of them suffered veto, both regarding Middle East. Once again the major concern of the Council was protection of civilians in an armed conflict. Massive uprisings and escalation of events related to the Arab Spring contributed it largely. Libya, for instance, suffered consequences related to this. Six resolutions were adopted demanding immediate ceasefire and imposing sanctions on the authorities. Still, the conflict between citizens and government security forces did not stop. Another very controversial topic discussed, was Palestinian membership in the United Nations. Palestinian officials announced application to full membership in the United Nations, and the decision was brought to the Security Council. As some member states had a clear stand regarding this question, some were hesitant. Many speculations about the voting turnout were raised as in media, so in academic field as well. It was very questionable whether the resolution will get nine necessary votes. Bosnia and Herzegovina was in a difficult situation, again, considering the internal decision making process. Most predictions were that it will abstain from voting considering that Serb member of the Presidency would not agree upon the issue. In any case, taking in account the veto that the United States would cast, this resolution would not be adopted. At the end, Palestinian government decided to withdraw the application.

The attitude of Bosnia and Herzegovina in the Security Council was not affected by other member states, but by its own internal issues, attitudes and goals. Issues related to Kosovo, Palestine, and perhaps even Iran, for instance, which were discussed in the Council support that. Both, internal and external affairs of a state influence its foreign policy. However, in this case, internal affairs prevailed. The subjective reasons of members of the Presidency affected the attitude in the Security Council.

It has been almost four years since the end of the mandate of Bosnia and Herzegovina in the Security Council. The country still struggles on its way to the membership in EU and NATO. Unlike predictions, only slight improvement has been made in this area as well as in economic and political field. On the other hand, Bosnia and Herzegovina is richer in experience which gained during the two-year mandate. The mandate in the Security Council was a learning experience which might serve well to the representatives in the Committee of Ministers of the Council of Europe whose current Chairman is from Bosnia and Herzegovina.

\section{References}

Avdović, Erol. (2012). Interview with Ivan Barbalić. Ambassador of Bosnia and Herzegovina. Publica Press, $<$ http://webpublicapress.net/barbalic-bili-smo-odlicni-u-vijecu/> (accessed June 3, 2015).

Barbalić, Ivan. (2015). Ambassador of Bosnia and Herzegovina. Skype interview.

Bosco, David. (2014). “Assessing the UN Security Council: A Concert Perspective," Global Governance 
(Boulder, Colorado: Lynne Rienner Publishers): 545-561.

Bosco, David. (2011). "Palestine: Vote-Counting on the Security Council," Foreign policy,

$<$ http://foreignpolicy.com/2011/09/20/palestine-vote-counting-on-the-security-council-updated/> (accessed May 22, 2015).

Custovic, Hamdija. (2011). "Bosnia and Herzegovina's Presidency over the UN Security Council," Bosniak (Congress of North American Bosniaks), <http:/www.bosniak.org/bosnia-and-herzegovinaspresidency-over-the-un-security-council/> (accessed May 9, 2015).

Domin, Thierry. (2003). "Bosnia and Herzegovina in Ten Flags,"” NATO,

$<$ http://www.nato.int/sfor/indexinf/articles/030512a/t030512a.htm (accessed May 8, 2015).

EUFOR BiH. (2015). "Political/Military Background,” EUFOR BiH,

$<$ http://www.euforbih.org/index.php?option=com_content\&view=article\&id=2821>

(accessed June 1, 2015).

FENA. (2012). "Uspješan mandat BiH u Vijeću sigurnosti Ujedinjenih naroda," Klix, <http://www.klix.ba/ vijesti/bih/uspjesan-mandat-bih-u-vijecu-sigurnosti-ujedinjenih-naroda/120102054> (accessed May 22, 2015).

Freund, Michael. (2014). "Fundamentally Freund: Israel's best friend in Europe," The Jerusalem, <http:// www.jpost.com/Opinion/Op-Ed-Contributors/Fundamentally-Freund-Israels-best-friend-inEurope-351233> (accessed September 1, 2015).

Moj Portal. (2010). "Glas BiH odlučuje o sankcijama Iranu?," Moj Portal, <http://www.mojportal.ba/ novost $/ 36806 />$ (accessed June 7, 2015).

Pilkington, Ed. (2011). "US vetoes UN condemnation of Israeli settlements," The Guardian,

$<$ http://www.theguardian.com/world/2011/feb/19/us-veto-israel-settlement> (accessed June 10, 2015).

Prica, Miloš. (2009). “Članstvo u SB UN donosi strane investicije,” Nezavisne novine, $<\mathrm{http}$ ://www.nezavisne. com/novosti/drustvo/Milos-Prica-Clanstvo-u-SB-UN-donosi-strane-investicije-48532.html > (accessed May 19, 2015).

Radio Sarajevo. (2010). "Vijeće sigurnosti UN-a usvojilo rezoluciju o sankcijama Iranu, "Radio Sarajevo, $<\mathrm{http}$ ://radiosarajevo.ba/novost/27670/vijece-sigurnosti-un-a-usvojilo-rezoluciju-o-sankcijama-iranu> (accessed June 3, 2015).

The Guardian. (2011). "Russia and China veto UN resolution against Syrian regime," The Guardian, <http:// www.theguardian.com/world/2011/oct/05/russia-china-veto-syria-resolution> (accessed June 10. 2015).

The United Nations. (2011a). "Briefing Security Council, Bosnia and Herzegovina High Representative Describes Most Serious, Direct Challenges to Peace Agreement Since Signed in 1995," The United Nations, <http://www.un.org/press/en/2011/sc10243.doc.htm> (accessed June 14, 2015).

The United Nations. (2010a). "Briefing Security Council, Secretary-General's Envoy in Kosovo Urges Pristina, Belgrade to Make Use of United Nations, European Efforts to Bridge Differences," The United Nations, <http://www.un.org/press/en/2010/sc10083.doc.htm> (accessed May 25, 2015).

The United Nations. "Charter of the United Nations," The United Nations, <http://www.un.org/en/documents/ charter/index.shtml> (accessed May 9, 2015).

The United Nations. (2012). "Civilian Protection Remains a top Security Council Agenda in 2011 amid Violent Suppression of Mass Protests, Birth of New Member State,” The United Nations, <http://www.un.org/ press/en/2012/sc10518.doc.htm> (accessed May 20, 2015).

The United Nations. (2011b). "Importance of Protecting Civilians during Armed Conflict Grows as Security Council Remains Active in Tackling Conflict-Related Crises Worldwide," The United Nations, <http:// www.un.org/press/en/2011/sc10147.doc.htm> (accessed May 20, 2015).

The United Nations. (2010b). "Internal Divisions Stalling Bosnia and Herzegovina's 'Great Strides' on International Stage, High Representative Tells Security Council,” The United Nations, <http://www. un.org/press/en/2010/sc9933.doc.htm> (accessed May 26, 2015).

The United Nations. (2010c). "Meeting records: The situation in Bosnia and Herzegovina," The Security Council, <http://www.un.org/en/ga/search/view_doc.asp?symbol=S/PV.6319> (accessed May 28, 2015).

The United Nations. (2010d). "Meeting records: The situation in Bosnia and Herzegovina," The Security Council,

$<$ http://www.un.org/en/ga/search/view_doc.asp?symbol=S/PV.6421> (accessed May 28, 2015).

The United Nations. "Member States of the United Nations," The United Nations. <http://www.un.org/en/ members/> (accessed May 9, 2015). 
The United Nations “Question of Palestine and the General Assembly," The United Nations. <http://unispal. un.org/unispal.nsf/ga.htm> (accessed June 10, 2015).

The United Nations. (2010e). "Security Council Authorizes for Another Year European Union Stabilization Force in Bosnia and Herzegovina, by 1948 (2010); NATO to Maintain Presence There," The United Nations, <http:/www.un.org/press/en/2010/sc10088.doc.htm> (accessed May 26, 2015).

The United Nations. (2011c). "Security Council Authorizes One-year Mandate Extension for European Union Multinational Stabilization Force in Bosnia and Herzegovina," The United Nations, <http://www. un.org/press/en/2011/sc10451.doc.htm> (accessed June 14, 2015).

The United Nations. (2010f). "Security Council Imposes Additional Sanctions on Iran, Voting 12 in Favour to 2 Against, with 1 Abstention," The United Nations, <http://www.un.org/press/en/2010/sc9948.doc. htm> (accessed June 5, 2015).

The United Nations. (2011d). "Security Council Told Political Stagnation, Backsliding in Bosnia and Herzegovina Highlight Need for Continued Presence of High Representative, European Force," The United Nations, <http://www.un.org/press/en/2011/sc10449.doc.htm> (accessed June 14, 2015).

The United Nations. (2010g). "Senior International Official, Briefing Security Council, Calls for End to 'Stagnation and Internal Disagreements' in Bosnia and Herzegovina," The United Nations, <http:// www.un.org/press/en/2010/sc10082.doc.htm> (accessed May 26, 2015).

The United Nations. "The Security Council" United Nations Security Council, <http://www.un.org/en/sc/> (accessed May 10, 2015).

Vanjskopolitička Inicijativa. (2011). "Non-permanent membership of Bosnia and Herzegovina in the United Nations Security Council 2010 - 2011: Challenges of the January 2011 Presidency," Vanjskopolitička inicijativa: 1-13. 